\title{
Gas-Cooled Fast Reactor Research and Development Roadmap
}

The INL is a

U.S. Department of Energy National Laboratory

operated by

Battelle Energy Alliance

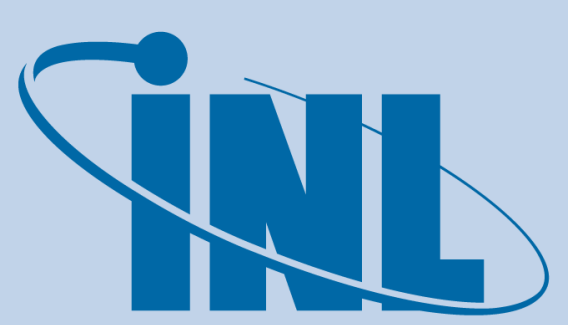

Idaho National Laboratory

June 2017

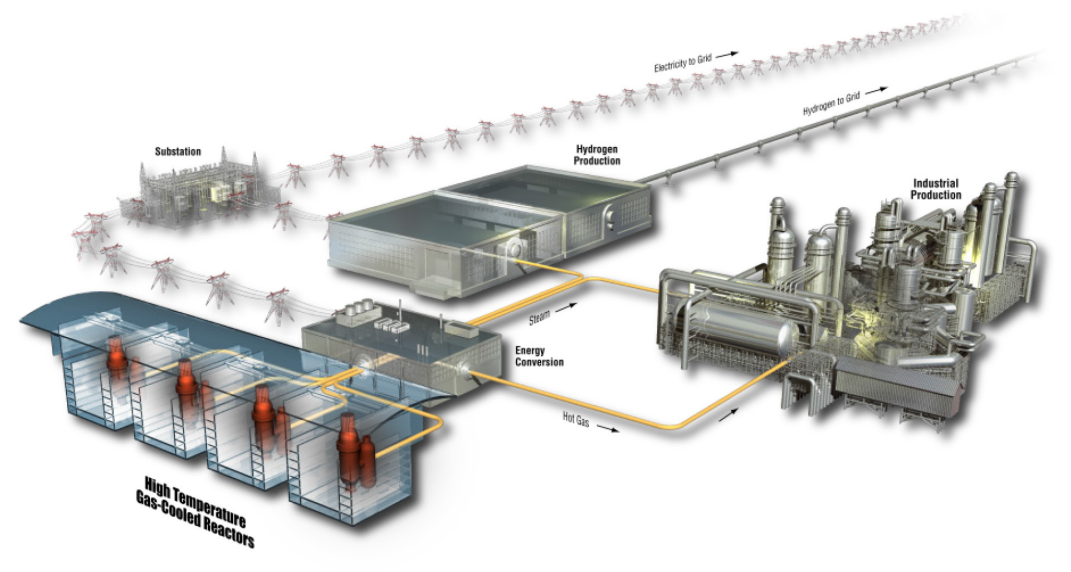




\section{DISCLAIMER}

This information was prepared as an account of work sponsored by an agency of the U.S. Government. Neither the U.S. Government nor any agency thereof, nor any of their employees, makes any warranty, expressed or implied, or assumes any legal liability or responsibility for the accuracy, completeness, or usefulness, of any information, apparatus, product, or process disclosed, or represents that its use would not infringe privately owned rights. References herein to any specific commercial product, process, or service by trade name, trade mark, manufacturer, or otherwise, does not necessarily constitute or imply its endorsement, recommendation, or favoring by the U.S. Government or any agency thereof. The views and opinions of authors expressed herein do not necessarily state or reflect those of the U.S. Government or any agency thereof. 
INL/EXT-17-41800

Revision 0

\section{Gas-Cooled Fast Reactor Research and Development Roadmap}

June 2017

\section{Idaho National Laboratory \\ INL ART TDO Program \\ Idaho Falls, Idaho 83415}

http://www.inl.gov

Prepared for the

U.S. Department of Energy

Office of Nuclear Energy

Under DOE Idaho Operations Office

Contract DE-AC07-05ID14517 



\section{Gas-Cooled Fast Reactor Research and Development Roadmap}

\section{INL/EXT-17-41800}

Revision 0

June 2017

Approved by:

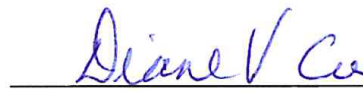

Diane V. Croson, Deputy Director

INL ART Technology Development Office

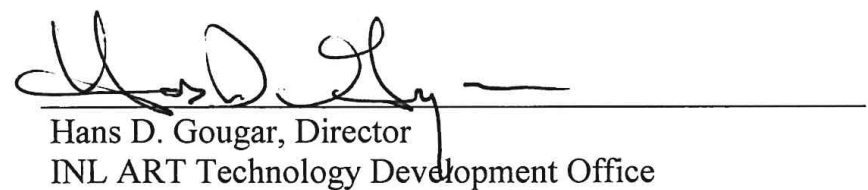

INL ART Technology Devdropment Office

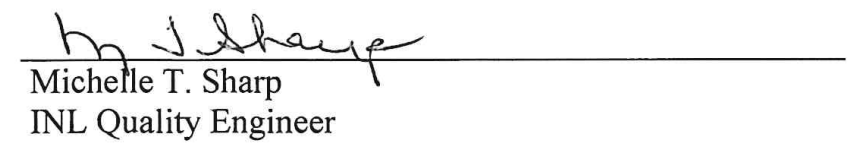

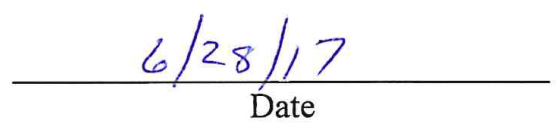

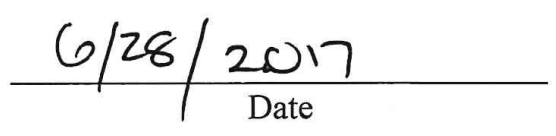

$\frac{6 / 28 / 17}{\text { Date }}$ 


\section{SUMMARY}

The U.S. Department of Energy (DOE) commissioned development of technology roadmaps for advanced (i.e., non-light water reactor) reactor concepts to help focus research and development funding over the next 5 years. The roadmaps show the research and development needed to support demonstration of an advanced, non-Light Water Reactor concept by 2030, consistent with the DOE's vision and strategy for development and deployment of advanced reactors. The starting point for the roadmaps is the technical readiness assessment performed as part of an advanced test and demonstration reactor study released in 2016 [12]. The roadmaps were developed based on a review of technical reports and vendor literature summarizing the technical maturity of each concept and outstanding research and development needs. Critical path tasks for specific systems were highlighted on the basis of time and resources needed to complete the tasks and the importance of the system to performance of the reactor concept.

The roadmaps are intended to be generic (i.e., not specific to a particular vendor's design); however, features of the General Atomics Energy Multiplier Module $\left(\mathrm{EM}^{2}\right)$ were included to provide specific examples for illuminating needed research and development tasks to be conducted in support of demonstration in the near future.

This report provides the roadmap for engineering demonstration of a gas-cooled fast reactor with an outlet temperature around $850^{\circ} \mathrm{C}$. The selection of tasks and associated timelines rely heavily on the Generation IV International Forum Technology Roadmaps [2,3] and more recent information provided by the gas-cooled fast reactor developer, General Atomics. 


\section{ACKNOWLEDGEMENTS AND DISCLAIMER}

The author wishes to thank Dr. Hangbok Choi and his colleagues at General Atomics for providing input to this document. This report was prepared by selected experts within the U.S. Department of Energy Complex who are familiar with the technology. It draws heavily on information obtained from openly available technical reports generated during the Next Generation Nuclear Plant Project and the U.S. Department of Energy Technical Review Panel that evaluated a number of advanced reactor concepts. 


\section{CONTENTS}

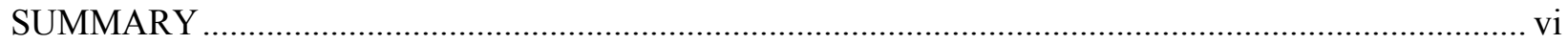

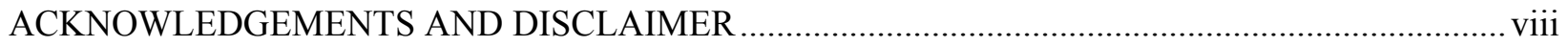

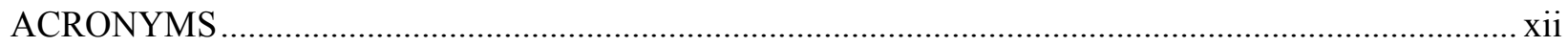

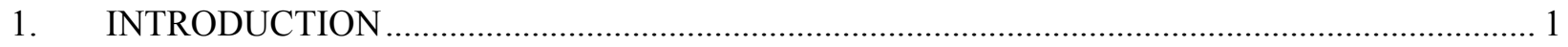

2. CONCEPT DESCRIPTION(S) AND TECHNOLOGICAL MATURITY .................................. 1

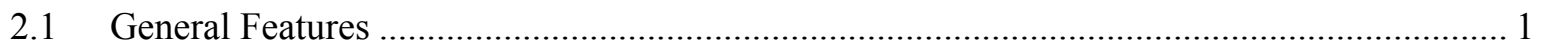

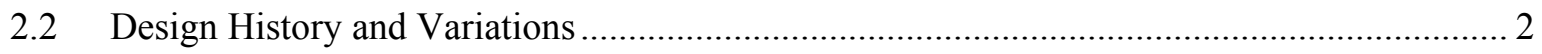

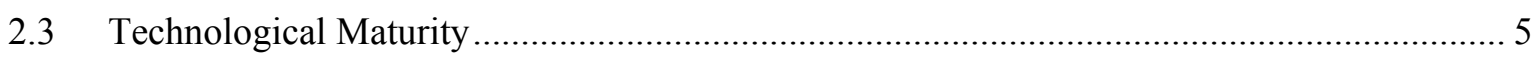

3. RESEARCH AND DEVELOPMENT NEEDS ...................................................................... 7

3.1 Common Research and Development Needs of Advanced Reactors.................................... 7

3.2 Gas-Cooled Fast Reactor Research and Development Needs............................................. 7

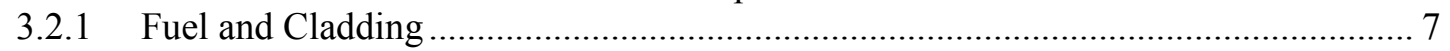

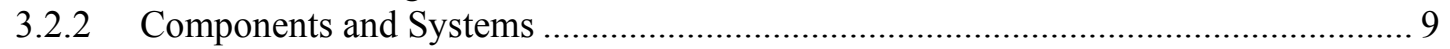

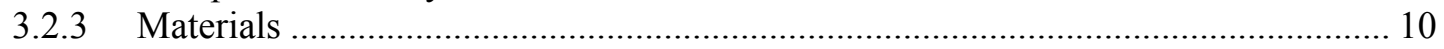

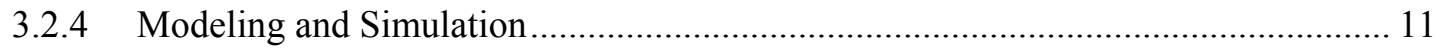

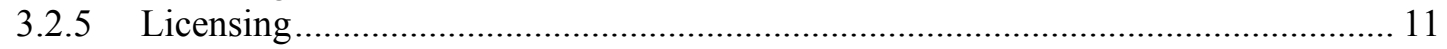

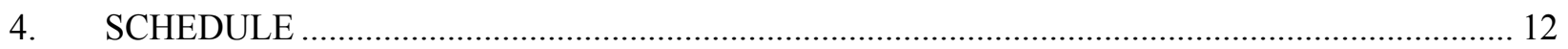

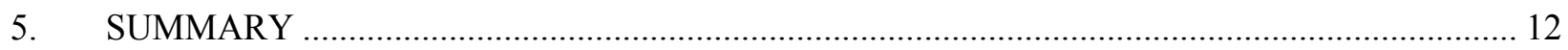

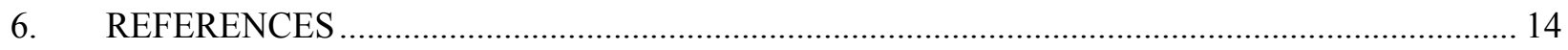

\section{FIGURES}

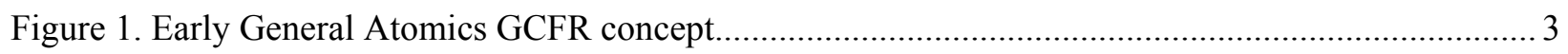

Figure 2. 2,400-MWt Generation IV reference concept. .................................................................... 4

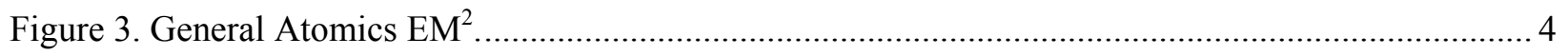

Figure 4. General Atomics $\mathrm{EM}^{2}$ core and fuel design. ................................................................... 5

Figure 5. Approximate schedule for supporting GFR engineering demonstration................................ 13 


\section{TABLES}

Table 1. Overall TRLs of advanced reactor concepts currently being pursued in the United

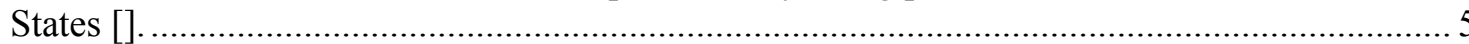

Table 2. TRLs for each system and subsystem of the General Atomics EM ${ }^{2}$ GFR with a combined cycle power conversion system (key subsystems are shaded) ................................................ 6

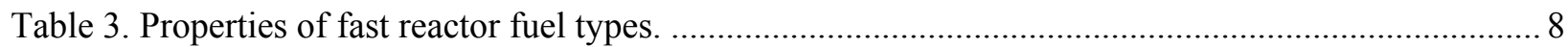

Table 4. Phases of nuclear fuel and material testing............................................................................. 8 


\section{ACRONYMS}

ART Advanced Reactor Technologies

ATR Advanced Test Reactor

ANL Argonne National Laboratory

DHR decay heat removal

DOE Department of Energy

$\mathrm{EM}^{2} \quad$ Energy Multiplier Module (General Atomics)

GBR gas breeder reactor

GCFR Gas-Cooled Fast Reactor

GFR gas-cooled fast reactor

HFIR High Flux Isotope Reactor

HTGR high temperature gas-cooled reactor

MSR molten salt reactor

MW megawatt

NRC Nuclear Regulatory Commission

NSTF Natural Convections Shutdown Heat Removal Test Facility

$\mathrm{R} \& \mathrm{D} \quad$ research and development

TRL technology readiness level

VHTR very high-temperature reactor 


\section{Gas-Cooled Fast Reactor Research and Development Roadmap}

\section{INTRODUCTION}

Among the advanced reactors being considered by vendors and governments, the gas-cooled fast reactor (GFR) possesses a relatively low technical maturity. No GFRs have operated even at a strictly experimental level, however, a number of design studies and some laboratory-scale testing of materials and fuels continue at modest levels in Europe and the United States. The GFR promises high fuel utilization of a fast spectrum reactor with a high outlet temperature that supports high-efficiency electricity generation and process heat for industrial applications.

This document describes the critical research and development (R\&D) needed to support engineering demonstration of a GFR by 2030. The major features and attributes of this reactor concept are shared among all pre-conceptual designs proposed to date, thus the roadmap proposed in this report can be considered applicable for the family. Nonetheless, features of the General Atomics Energy Multiplier Module (EM $\left.{ }^{2}\right)$ were used as specific examples to help illuminate technical readiness and R\&D needs.

\section{CONCEPT DESCRIPTION(S) AND TECHNOLOGICAL MATURITY}

\subsection{General Features}

The typical GFR design features an unmoderated, helium-cooled core with a ceramic fuel that operates at high temperatures (i.e., $1,450^{\circ} \mathrm{C}$ in the General Atomics design) and cladding temperatures as high as $1,000^{\circ} \mathrm{C}$. The fast neutron spectrum supports burning of uranium, thorium, or plutonium with minimal buildup of minor actinides. Very high fuel utilization can be achieved if the fuel is recycled. Through the combination of a fast-neutron spectrum, lack of a fertile blanket, and full recycling of actinides, GFRs could minimize production of long-lived radioactive waste isotopes, while burning available fissile and fertile materials (including depleted uranium from enrichment plants). The GFR reference concept described below assumes an integrated, onsite spent fuel treatment and refabrication plant. However, this roadmap outlines the R\&D needed to demonstrate only the reactor itself; fuel reprocessing technology needs are not addressed.

As with thermal-spectrum, helium or molten salt-cooled reactors (i.e., the high-temperature gas reactors [HTGR]), the high outlet temperature of the helium coolant makes it possible to deliver electricity, hydrogen, or process heat with high thermodynamic efficiency. Most GFR designs would drive a direct-cycle (i.e., helium) Brayton power conversion system for electricity and would generate process heat for industrial applications. GFRs would drive either a gas turbine (i.e., Brayton) cycle drive or a steam (i.e., Rankine) cycle with or without an intermediate heat exchanger.

Some of the more distinguishing features can be best highlighted by comparing the GFR to metal-cooled fast reactors and gas-cooled thermal reactors [1].

GFRs would have the following advantages when compared to metal-cooled fast reactors:

- Chemical compatibility with water, obviating the need of an intermediate coolant loop, and generally good chemical compatibility with structural materials.

- Negligible activation of coolant.

- Optically transparent, simplifying fuel shuffling operations and inspection.

- Gas coolants cannot change phase in the core, reducing the potential of reactivity swings under accidental conditions. 
- Reduction of the positive void effect typically associated with sodium.

- Gas coolants generally allow a harder neutron spectrum, which increases the breeding potential of the reactor.

Compared to the graphite-moderated HTGR, the fast-spectrum GFR can support high fuel utilization and even breeding. Along with elimination of the graphite moderator, the waste volume of GFR spent fuel would be a small fraction of that generated by an HTGR using a once-through fuel 'cycle.'

The disadvantages of the GFR relative to the metal-cooled concepts are as follows:

- Higher pumping power required to cool the core.

- The need to maintain high pressure in the system; typically around $7 \mathrm{MPa}$ for helium and around $25 \mathrm{MPa}$ for supercritical $\mathrm{CO}_{2}$; to support sufficient cooling of the fuel.

- Depending on fuel geometry, gas cooling often requires artificial roughening of the metallic cladding to maintain an acceptable cladding temperature, resulting in an increased pressure drop over the core and a higher requirement for pumping power. Silicon carbide ( $\mathrm{SiC}$ ) cladding does not require roughening.

- High coolant flow velocity can lead to significant vibrations of the fuel pins. Grid supports may prevent these vibrations.

- The high power density, relative to the light water reactor and HTGR assumed in some designs, and lack of thermal capacity of the coolant require a reliable and fast response from a decay heat removal (DHR) system with considerable pumping power. $\mathrm{EM}^{2}$ would have a lower power density $\left(58 \mathrm{~W} / \mathrm{cm}^{3}\right)$ that would place lower demands on the DHR system.

Similarly, the lack of graphite means GFR has no thermal buffer to absorb the energy of a transient. In the event of a loss of forced cooling such as a blower trip, the core temperatures would quickly rise to failure temperatures without a robust (and probably active) DHR system. This places additional emphasis on the need to identify and qualify a temperature-tolerant fuel form.

\subsection{Design History and Variations}

An overview of different GFR conceptual designs and development programs is provided in reference [1] (van Rooijen) and the Generation IV International Forum Technology Roadmap [2] and 2014 update [3].

GFR concepts were first proposed in the 1960s. They are all characterized by a ceramic fuel form, temperature-resistant alloys or refractory metals, and powerful DHR systems. Variations on the GFR theme emerged early in development of the concept, mainly in fuel geometry, thermal power, and operating temperatures; however, none of these variations pointed to a significant change in performance characteristics.

One of the earliest concepts for a GFR was developed by General Atomics (Figure 1). Their Gas-Cooled Fast Reactor (GCFR) would have produced $835 \mathrm{MW}$ of thermal power with mixed oxide fuel arranged in pins and a coolant outlet temperature of $550^{\circ} \mathrm{C}$ [1]. The experimental program supporting GCFR development included critical reactor investigations under GCFR-PROTEUS (1972 through 1979) that were aimed at validating data sets and calculational methods for the design of fast breeder reactors cooled with gas $[4,5,6,7]$.

In the late 1960s, Germany proposed various concepts with pin-type fuel in stainless steel cladding, a pressurized concrete pressure vessel, and driving a steam cycle. Three gas breeder reactor (GBR) concepts had higher power ratings (greater than 3,000 MW) and either pin-type fuel (GBR-1), a coated particle fuel formed into either annular fuel elements (GBR-2), or a packed bed of fuel spheres through which helium flowed radially (GBR-3). All were meant to breed fuel, typically with conversion ratios of about 1.4. The need to minimize neutron leakage to support breeding forced the cores to be relatively large and of high power, further exacerbating the ability to remove decay heat. In addition, difficulty in fabricating structural components often led to lower-temperature designs that use more traditional fast reactor cladding and structural alloys. 
A United Kingdom program that ran into the 1970s produced a design using technologies developed for their sodium fast reactor program and the $\mathrm{CO}_{2}$ coolant used in their early advanced gas-cooled reactors.

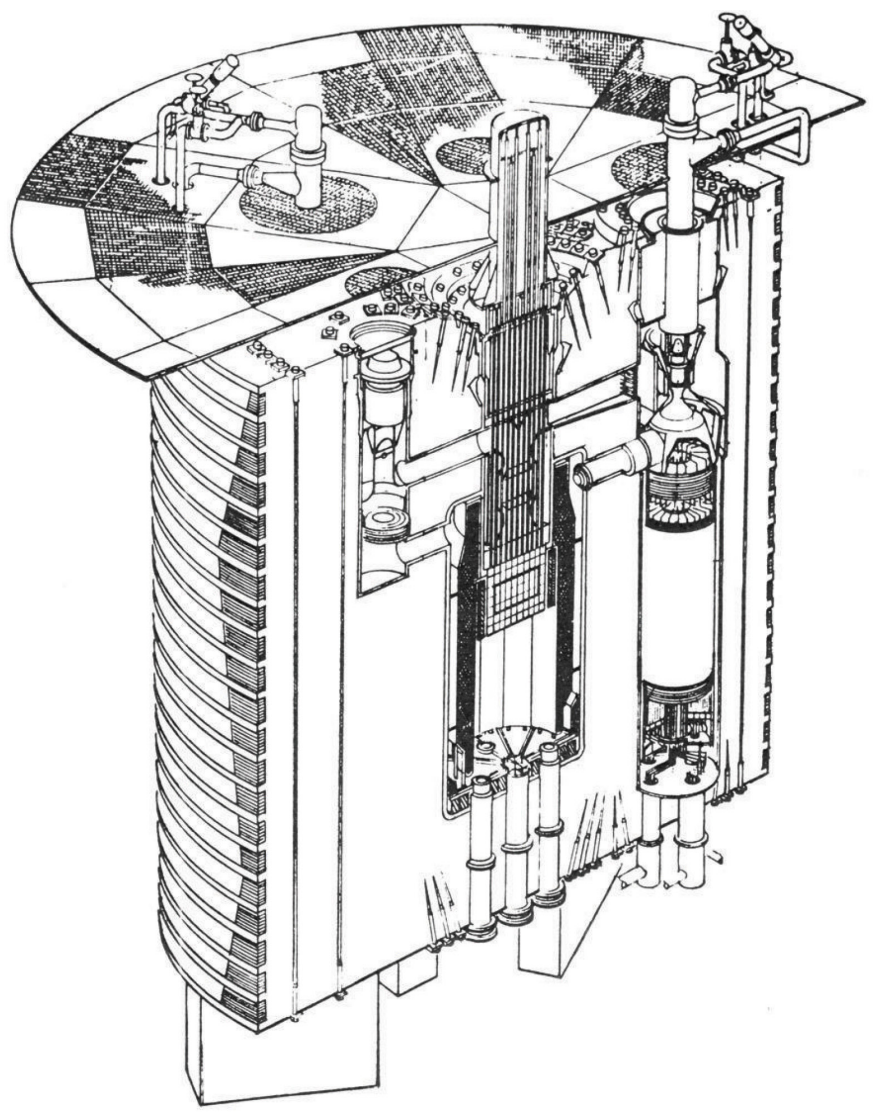

Figure 1. Early General Atomics GCFR concept.

Similarly, Japan developed a 2,400-MWt GFR concept as part of their fast reactor development program. This core would have used a nitride-based kernel surrounded by multiple layers made of TiN and other compounds. Structural materials would have been made with SiC. The design effort terminated in the late 1990s.

Interest in GFR reawakened globally with the Generation IV Initiative. Europe and Japan cooperated on development of a reference design for a 600-MWt GFR [3]. Breeding as an objective was mostly abandoned, but high conversion (i.e., a conversion ratio of about 1) was still sought to meet fuel utilization and waste minimization goals. The initially small Generation IV reference design (i.e., 600-MWt) did not appear to meet fuel utilization targets; therefore, it was superseded by the 2,400-MWth design illustrated in Figure 2 [8]. The 600-MWth design is still considered an option for a gas-cooled small modular reactor, if high conversion is not required.

The direct power conversion cycle chosen as a reference in the original roadmap is no longer considered the only option. It was originally assumed the HTGR community would develop this technology in projects such as Pebble Bed Modular Reactor (PBMR) in South Africa and the Gas Turbine Modular Helium Reactor (GT-MHR) in the United States and Russia.

The power conversion system for referencing the Generation IV concept is the combined (i.e., gas-steam) cycle proposed by AREVA for their ANTARES graphite-moderated very high-temperature reactor (VHTR) [9].

Recently, General Atomics embarked on a new GFR development project featuring their $\mathrm{EM}^{2}$ [10]. This conceptual design features a novel power conversion system and a direct helium Brayton cycle (i.e., $850^{\circ} \mathrm{C}$ 
outlet), with the heat that has been rejected through the pre-cooler used to drive an organic Rankine cycle (Figure 3).

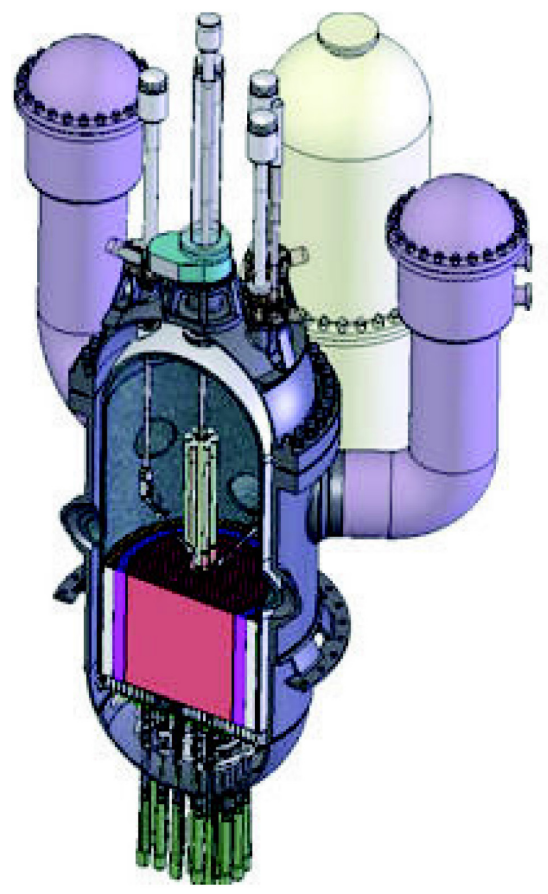

Figure 2. 2,400-MWt Generation IV reference concept.

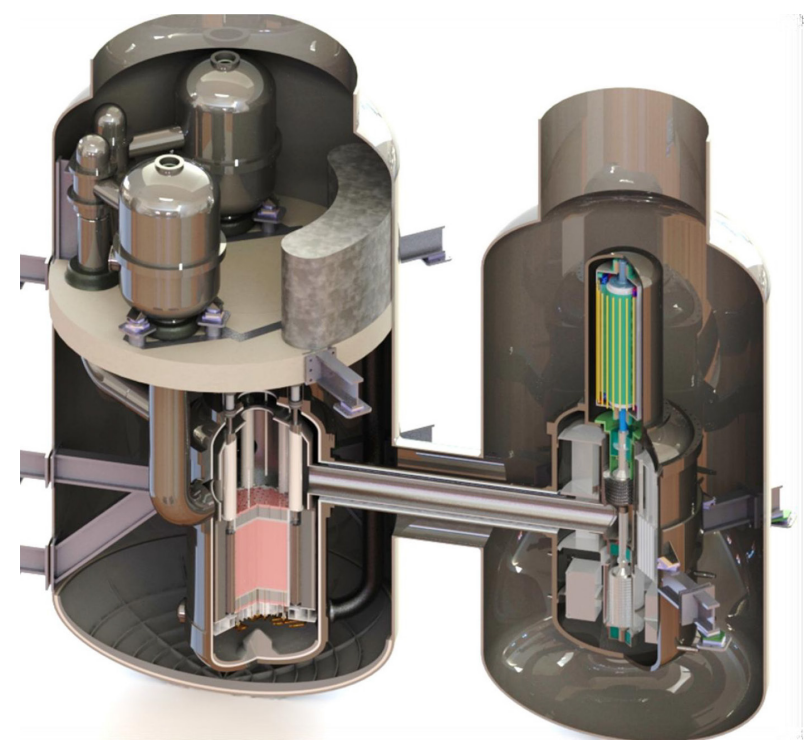

Figure 3. General Atomics EM².

The $\mathrm{EM}^{2}$ core would consist of fuel assemblies comprised of 91 annular fuel rods fabricated from uranium carbide particles sintered into pellets (Figure 4, right). The porosity of the pellets allows the particles to swell and the fission gases to vent. The fuel rods would be clad in a $\mathrm{SiC}$ composite material ( $\mathrm{SiC}-\mathrm{SiC}$ ).

The core is surrounded by a $\mathrm{Zr}_{3} \mathrm{Si}_{2}$ inner reflector and graphite outer reflector to reduce fluence to the pressure vessel (Figure 4, left). 

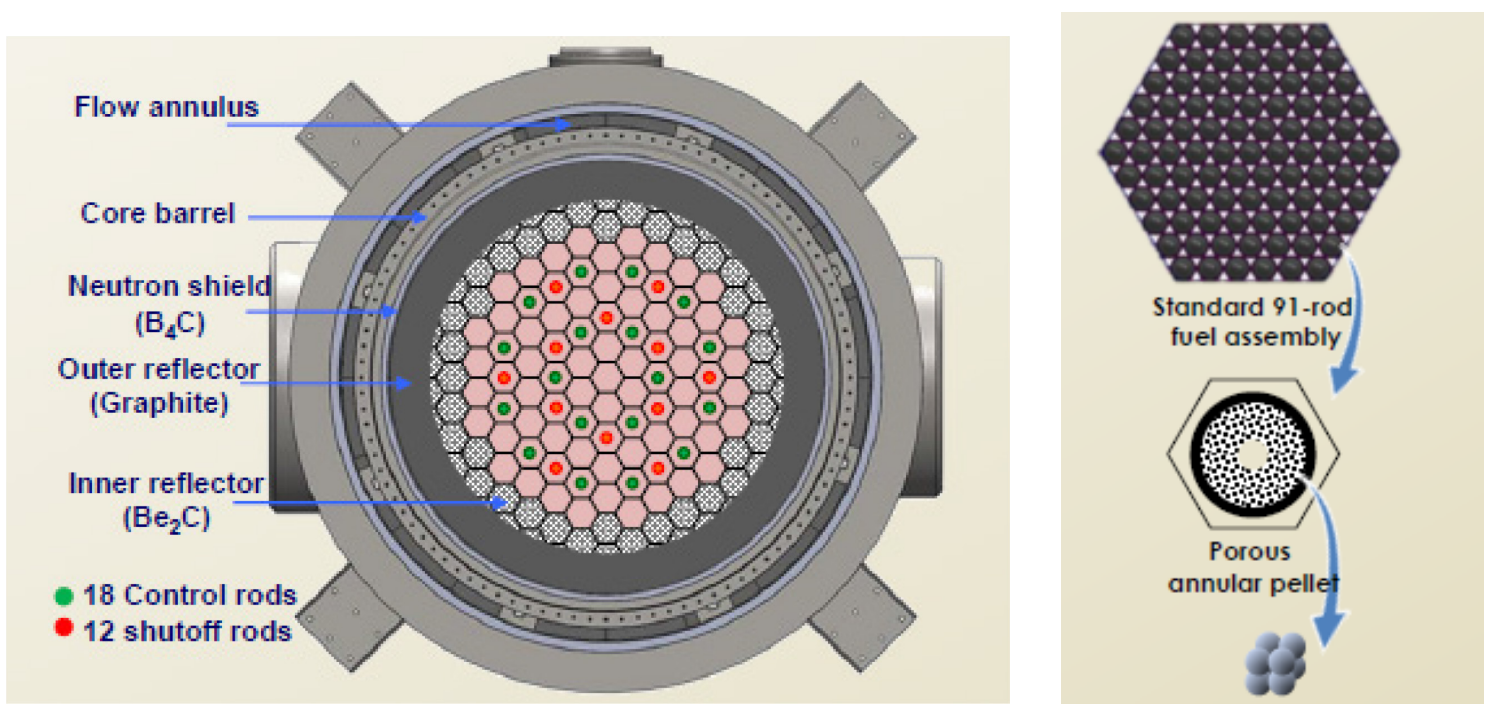

Figure 4. General Atomics $\mathrm{EM}^{2}$ core and fuel design.

\subsection{Technological Maturity}

In 2014, as part of a study examining the needs and options for non-light water reactor demonstration reactors and irradiation test reactors, technological maturity assessments were performed for the Generation IV advanced reactor concepts by a team of U.S. DOE national laboratory technical staff. As available, design information from vendors pursuing a concept helped to assess the maturity of the family. For each concept, the technological maturity of each subsystem and the encompassing systems were evaluated based on available vendor design information and recent technology assessments performed by the vendors or by DOE. Technology readiness was quantified using the scale established by DOE [11]. The overall maturity of the concept was defined as the minimum technology readiness level (TRL) for a set of key subsystems required for a concept to achieve its performance goals. Table 1 lists the overall TRL for each reactor concept evaluated in the study.

Table 1. Overall TRLs of advanced reactor concepts currently being pursued in the United States [12].

\begin{tabular}{|c|c|c|c|c|c|c|c|c|}
\hline & \multirow{2}{*}{$\begin{array}{l}\text { GFR } \\
\text { EM }^{2}\end{array}$} & \multirow{2}{*}{$\begin{array}{c}\text { Lead- } \\
\text { Cooled Fast } \\
\text { Reactor } \\
\text { Gen4 } \\
\end{array}$} & \multicolumn{2}{|c|}{$\begin{array}{l}\text { Sodium Fast } \\
\text { Reactor }\end{array}$} & \multicolumn{2}{|c|}{ HTGR } & \multicolumn{2}{|c|}{ MSR } \\
\hline & & & AFR-100 & PRISM & SC-HTGR & VHTR & FHR & LF-MSR \\
\hline $\begin{array}{l}\text { Overall Technology Readiness } \\
\text { Level }\end{array}$ & 2 & 3 & 3 & 5 & 5 & 3 & 3 & 3 \\
\hline
\end{tabular}

Table 2 lists the TRLs assigned by the assessment team to the General Atomics EM ${ }^{2}$ systems and subsystems. Major technologies used in all GFRs proposed to date are largely common in a way that these TRL values can be considered representative of the concept. The shaded cells in the TRL value columns indicate the key systems and subsystems needing to be developed fully in order for a design to achieve its performance objectives. It should be noted that these TRLs represent the consensus opinion of the authors for the technology assessment and may not match those reported by the vendor.

As mentioned above, most GFR concepts, including the original 600- MWt Generation IV reference design, would use a gas turbine power conversion system operating in the $250-850^{\circ} \mathrm{C}$. The technology of such a system is to a large extent the same as that proposed for the VHTR, and thus a reasonable assessment of the maturity can be obtained from the maturity assessment conducted for the Next Generation Nuclear Plant program [13]. For a GFR driving a steam cycle, as with the current Generation IV reference design, Reference [14] describes the state of high temperature nuclear steam systems. For a gas turbine system driven by very high temperature helium, Reference [15] describes the state of Brayton cycle technology. 
Table 2. TRLs for each system and subsystem of the General Atomics EM ${ }^{2}$ GFR with a combined cycle power conversion system (key subsystems are shaded).

\begin{tabular}{|c|c|}
\hline & $\begin{array}{l}\text { GFR } \\
\text { EM }^{2}\end{array}$ \\
\hline Nuclear Heat Supply & 2 \\
\hline Fuel Element (fuel, cladding, assembly) & 2 \\
\hline Reactor Internals & 3 \\
\hline Reactivity Control & $6^{\mathrm{a}}$ \\
\hline Reactor Enclosure & 4 \\
\hline Operations/Inspection/Maintenance & 4 \\
\hline Core instrumentation & 3 \\
\hline Heat Transport & 3 \\
\hline Coolant Chemistry Control/Purification & $7^{\mathrm{a}}$ \\
\hline Primary Heat Transport System (hot duct) & 6 \\
\hline Intermediate Heat Exchanger (if applicable) & $\mathrm{NA} / 3$ \\
\hline Pumps/Valves/Piping & 5 \\
\hline Auxiliary cooling & 6 \\
\hline Residual Heat Removal & 3 \\
\hline Power Conversion & 3 \\
\hline Turbine & 5 \\
\hline Compressor/Recuperator (Brayton) & $5^{\mathrm{a}}$ \\
\hline Reheater/Superheater/Condenser (Rankine) & NA \\
\hline Steam generator & $7^{\mathrm{a}}$ \\
\hline Pumps/Valves/Piping & $6^{\mathrm{a}}$ \\
\hline Process heat plant (e.g., $\mathrm{H}_{2}$ ) & $\mathrm{NA} / 3$ \\
\hline Balance of Plant & 6 \\
\hline Fuel handling and Interim Storage & 6 \\
\hline Waste Heat Rejection & 7 \\
\hline Instrumentation and Control & 7 \\
\hline Radioactive Waste Management & 6 \\
\hline Safety & 2 \\
\hline Inherent (passive) Safety Features & 3 \\
\hline Active Safety System & 2 \\
\hline Licensing & 1 \\
\hline Safety Design Criteria and Regulations & 3 \\
\hline Licensing Experience & 1 \\
\hline Safety and Analysis Tools & 3 \\
\hline FUEL CYCLE & 3 \\
\hline RECYCLED FUEL FABRICATION TECHNOLOGY & 3 \\
\hline Used Fuel Separation Technology & 3 \\
\hline Safeguards & 3 \\
\hline $\begin{array}{l}\text { Proliferation Resistance - Intrinsic Design Features (e.g., special nuclear } \\
\text { material accountability) }\end{array}$ & 3 \\
\hline Plant Protection - Intrinsic Design Features & 3 \\
\hline
\end{tabular}

a. Updated since the release of [12]. 


\section{RESEARCH AND DEVELOPMENT NEEDS}

\subsection{Common Research and Development Needs of Advanced Reactors}

The technology maturity assessment report [12] identified key subsystems that must be matured in any reactor system for it to achieve its performance and safety goals. Any roadmap must include development of these on its critical path to near-term deployment. Other systems and subsystems must be developed or adopted in order for nominal operational readiness and longer-term performance goals.

Several advanced reactor concepts may possess common systems and subsystems. Systems or subsystems common to the multiple reactor concepts include the following:

- Tristructural isotropic fuel and graphite (VHTR, solid-fueled molten salt reactor [MSR])

- Core instrumentation (VHTR, GFR, solid or liquid-fueled MSR)

- High-temperature structural alloys and joining techniques (VHTR, GFR, MSR)

- Gas Brayton cycle (GFR, MSR)

- Supercritical $\mathrm{CO}_{2}$ power conversion system (advanced sodium fast reactor 100, MSR, and lead-cooled fast reactor, VHTR)

- Multi-module control (all)

- Reactor vessel cooling (VHTR, sodium fast reactor, and MSR)

As described above, the GFR power conversion system is largely the same as that of the HTGR; therefore, both systems would benefit from R\&D performed on power conversion components and materials. However, the GFR core is subject to operating conditions that are quite different from both the HTGR and the metal-cooled fast reactors. Therefore, for the GFR, development and qualification of fuel and in-core structural materials are most significant in terms of time, expense, and capabilities of facilities. In particular, the need for in-pile testing (preferably in a fast spectrum) of fuels and materials is the main item on the critical path to deployment of the GFR. Another critical path item is design and testing of DHR systems. The following subsection describes these and other R\&D needs in more detail.

\subsection{Gas-Cooled Fast Reactor Research and Development Needs}

\subsubsection{Fuel and Cladding}

The biggest task, by far, that needs to be performed before a GFR can be deployed is developing and qualifying fuel and the cladding that encapsulates it. The core can be designed so that fuel operates at a temperature comparable to that of an HTGR (i.e., about $1,000^{\circ} \mathrm{C}$ ); however, in some designs, it can be higher (i.e., about 1,300 to $1,500^{\circ} \mathrm{C}$ ) for the $\mathrm{EM}^{2}$ and 2,400-MWt Generation IV reference design [16]. More challenging is that the temperatures of the fuel and cladding must withstand accident conditions that can be as high as $2,000^{\circ} \mathrm{C}$. Furthermore, these materials are subjected to much higher damage rates due to the fast flux levels to which they are subjected. The reference value for the 600-MWt Generation IV GFR damage rate is 60 displacements per atom at a burnup of 5\% fissions per initial metal atom [8]. This is far higher than what is attained for thermal spectrum reactors; even for high flux test reactors that are currently the only option for testing fuels and materials.

Carbide and nitride fuels are considered for GFRs because they possess the high melting points of oxide fuels but have substantially higher thermal conductivities. This heat can be transported out of the fuel more easily during an accident scenario, reducing the peak temperatures likely to be attained. Table 3 shows the properties of different fuels proposed for fast reactors [17]. 
Table 3. Properties of fast reactor fuel types.

\begin{tabular}{lcccc}
\hline & $\begin{array}{c}\text { Metal } \\
\text { U-20Pu-10Zr }\end{array}$ & $\begin{array}{c}\text { Oxide } \\
\text { UO-20PuO2 }\end{array}$ & $\begin{array}{c}\text { Nitride } \\
\text { UN-20PuN }\end{array}$ & $\begin{array}{c}\text { Carbide } \\
\text { UC-20PuC }\end{array}$ \\
\hline Heavy Metal Density $\left(\mathrm{g} / \mathrm{cm}^{3}\right)$ & 4.1 & 9.3 & 13.1 & 12.4 \\
Melting Temperature $(\mathrm{K})$ & 1,350 & 3,000 & 3,035 & 2,575 \\
Thermal Conductivity $(\mathrm{W} / \mathrm{cmK})$ & 0.16 & 0.023 & 0.26 & 0.20 \\
Fuel-Cladding Solidus (K) & 650 & 1,675 & 1,400 & 1,390 \\
Coefficient of Thermal Expansion $\left(\mathrm{K}^{-1}\right)$ & $17 \mathrm{E}-6$ & $12 \mathrm{E}-6$ & $10 \mathrm{E}-6$ & $12 \mathrm{E}-6$ \\
\hline
\end{tabular}

Nitride and carbide fuels have not been developed and qualified for reactor use. An extensive testing and qualification effort is therefore required to support their use in a reactor demonstration. This is a four-phase process illustrated in Table 4 and adapted from Reference [18].

Table 4. Phases of nuclear fuel and material testing.

\begin{tabular}{|c|c|c|c|}
\hline $\begin{array}{c}\text { Selection of Potential } \\
\text { Candidates }\end{array}$ & $\begin{array}{c}\text { Laboratory-Scale: } \\
\text { Concept, Definition, and } \\
\text { Feasibility } \\
\end{array}$ & $\begin{array}{l}\text { Improvement and } \\
\text { Scale-Up }\end{array}$ & $\begin{array}{l}\text { Qualification and } \\
\text { Demonstration }\end{array}$ \\
\hline $\begin{array}{l}\text { - Early scoping studies } \\
\text { to measure basic } \\
\text { properties } \\
\text { - Establish performance } \\
\text { criteria } \\
\text { - Identify options and } \\
\text { parameters for testing }\end{array}$ & $\begin{array}{l}\text { - Investigate the range of } \\
\text { fuel types } \\
\text { - Down-select and } \\
\text { establish a reference } \\
\text { design } \\
\text { - Fill in knowledge gaps }\end{array}$ & $\begin{array}{l}\text { - Best results of } \\
\text { laboratory-scale tests } \\
\text { - Scale-up of fabrication } \\
\text { process to pilot or } \\
\text { engineering scale } \\
\text { - Process optimization } \\
\text { - Performance } \\
\text { demonstration } \\
\text { - Validation of the fuel } \\
\text { fabrication process }\end{array}$ & $\begin{array}{l}\text { - Test large quantities } \\
\text { of rods, plates, or } \\
\text { particles } \\
\text { - Production-scale } \\
\text { fabrication process } \\
\text { - Statistical } \\
\text { demonstration of } \\
\text { performance under } \\
\text { anticipated and } \\
\text { bounding reactor } \\
\text { conditions } \\
\text { - Validation of } \\
\text { performance models }\end{array}$ \\
\hline \multicolumn{2}{|c|}{ Up to 8 years } & 5 to 8 years & 8 to 15 years \\
\hline
\end{tabular}

Some experience with carbide fuel is being acquired in the Indian sodium fast breeder test reactor, which uses a mixed carbide driver fuel. It has reached a burnup of $155 \mathrm{GWd} / \mathrm{t}$ with a relatively high linear power $[19,20]$. Because the fast breeder test reactor is a sodium-cooled reactor, however, the fuel burnup performance is not directly transferrable to the GFR carbide fuel.

Early activities in a phase can overlap the later activities of the previous phase, so the entire process, if adequately funded, can take between 15 and 25 years. This is consistent with fuel development and qualification in the Advanced Gas Reactor (AGR) tristructural isotropic (TRISO) Fuel Program currently underway [21]. It began in 2003 with a primary candidate (UCO kernels) and a secondary candidate $\left(\mathrm{UO}_{2}\right.$ kernels), both in a TRISO coating design; at current funding levels activities will be completed around 2023.

Fuels (i.e., nitride or carbide) for GFRs have been proposed. Preliminary irradiation testing has been conducted; therefore, fuel development can be considered to be in the second phase (i.e., laboratory-scale) of testing. However, the difficulty with completing the program in a timely manner is the lack of a fast spectrum materials irradiation facility. There are very few fast spectrum test reactors operating in the world today and none operating in the United States. The Advanced Test Reactor (ATR) and High Flux Isotope Reactor (HFIR) boast some of the highest fluxes of any materials test reactors, but mainly in the thermal energy range. Practically speaking, this means that fuels tested in the ATR and HFIR can achieve high burnup, but low 
accumulated damage rates (i.e., less than 10 displacements per atom/year). Eight to ten years of continuous irradiation would be needed to achieve the desired irradiation performance data.

Cladding must meet rigorous in-core service specifications for length, diameter, surface roughness, apparent ductility, level of leak tightness (including the potential need of a metallic liner on the clad), compatibility with helium coolant (plus impurities), and anticipated irradiation conditions (spectrum, temperature, chemistry). Needs include fabrication capacities and material characterization under normal and accident conditions for fresh and irradiated fuel. Target criteria are as follows:

- Clad temperature of $1,000^{\circ} \mathrm{C}$ during normal operation

- No fission product release for a clad temperature of $1,600^{\circ} \mathrm{C}$ for a few hours

- Maintaining the core-cooling capability up to a clad temperature of $2,000^{\circ} \mathrm{C}$.

Under the Generation IV Program, a consortium of four countries (i.e., the Czech Republic, Hungary, Poland, and the Slovak Republic) plan to build an experimental GFR (ALLEGRO) to serve as both a demonstration of GFR systems and as a fuel testing platform. ALLEGRO would be the first fast spectrum gas-cooled reactor to be constructed and would also serve as a test bed for developing and qualifying the high-temperature, high-power density fuel and cladding that is required for a commercial-scale high-temperature GFR. This fuel qualification would be carried out at full scale at representative temperatures, coolant conditions, and with correct neutron spectrum and flux.

Different cladding concepts, including the SiC-SiC cladding proposed by General Atomics for the $\mathrm{EM}^{2}$, would also require a lengthy testing and qualification process using a fast spectrum test reactor. This cladding concept is being studied under contract with Westinghouse as part of the DOE Accident-Tolerant Fuels Program. As a schedule reference, the graphite characterization and qualification program currently being conducted by the DOE Advanced Reactor Technologies (ART) program for HTGR started in 2005 and will be completed by 2026 .

Any fast spectrum test reactor would supply the fast fluence levels needed to qualify GFR fuels and materials. In a sodium-cooled fast test reactor such as the (now inoperable) Fast Flux Test Facility, test trains could be configured to test nitride and carbide fuels under near prototypical conditions. With a well-funded government effort to build a fast spectrum materials test reactor, this capability could be available around 2030 to start a GFR qualification campaign. This would support a full GFR demonstration system coming online 10 to 15 years later.

A combined engineering demonstration and materials irradiation campaign, such as envisioned for ALLEGRO, is a potential pathway for development of GFR technology by 2035.

\subsubsection{Components and Systems}

3.2.2.1 Out-of-Pile Experimental Facilities for Qualification of the Main Systems. In terms of neutronics and zero-power reactor needs, existing calculational tools and nuclear data libraries have to be validated for GFR designs. The wide range of validation studies on sodium-cooled fast reactors must be complemented by specific experiments that incorporate the unique aspects of gas-cooled designs, including: slightly different spectral conditions, innovative materials and various ceramic materials (UC, $\mathrm{PuC}, \mathrm{SiC}, \mathrm{ZrC}$, $\mathrm{Zr}_{3} \mathrm{Si}_{2}$ ), and unique abnormal conditions (i.e., depressurization and steam ingress).

For core thermal hydraulics, air and then helium tests on subassembly mock-ups are necessary to assess heat transfer and pressure drop uncertainties of the specific GFR technology selected. A large-scale demonstration of the passive DHR system will be required (air and then helium tests). Testing of this system and other transient behavior must be built into the licensing process.

Development and qualification of components for heat transfer out of the core and power conversion are similar to those identified for HTGR, but with some additional requirements, specifically with respect to the following: 
- Thermal barriers - During normal operation, GFR metallic structures are protected from the hot $\left(850^{\circ} \mathrm{C}\right)$ helium flow by thermal barriers. These thermal barriers must continue to be effective during transients, typically up to $1,250^{\circ} \mathrm{C}$ for 1 hour, withstand helium velocities of about $60 \mathrm{~m} / \mathrm{s}$, and depressurization rates in the range of $2 \mathrm{MPa} / \mathrm{s}$. GFR-specific solutions must be developed and qualified in the relevant facilities.

- Valves and check-valves -Safety demonstration of GFRs relies on continuous core cooling by gas circulation, either through normal loops or dedicated DHR loops for which it is necessary to isolate the main loops and open the DHR loops with a high degree of reliability. Valves and check-valves are critical components of GFRs. Qualification tests of candidate technologies for these components are needed and must be performed using a dedicated helium loop.

- Instrumentation -Development of instrumentation that can survive under GFR conditions is one of the main challenges of GFRs. In particular, the main safety issue concerns temperature measurement at the core outlet; this measurement is taken in order to detect hot spots on the fuel cladding or fuel assembly plugging. The primary development objective is reduction of measurement uncertainties and development of innovative measurement methods using, if possible, helium transparency. This challenge is shared by HTGRs, but at a higher fluence rate. An instrumentation R\&D program includes core temperature measurements, monitoring of structural temperatures, and optical viewing during the fuel handling and maintenance phases.

- DHR systems - The need to ensure robust DHR without external power input, even under depressurized conditions, is regarded as a requirement. Previous concepts used electrically (battery) driven blowers at low pressure. Although a given plant design may not use diesel power units that would need protection from potential flooding, the integrity of the electrical infrastructure following an extreme event must be maintained. Self-powered systems are being explored that do not require external power supplies; however, these systems are still only conceptual in nature.

The Natural Convection Shutdown Heat Removal Test Facility (NSTF) at Argonne National Laboratory (ANL) was constructed to perform ex-core heat removal studies. In 2016, ANL completed a series of tests on a one-half scale, air-cooled reactor cavity cooling system. The hardware is now being reconfigured with water-cooled panels. These tests provide valuable validation data for safety analysis models. Originally designed to support PRISM (General Electric) sodium-cooled reactor development and licensing, the NSTF could be re-configured to study GFR ex-vessel cooling.

\subsubsection{Materials}

A candidate for the GFR pressure vessel is Modified 9Cr1Mo (modified Grade 91) steel. This alloy is being considered for the pressure vessels of other advanced reactors, including VHTRs. Mod 9Cr1Mo has already been used in conventional power plants and is also supported by significant R\&D test results from past and current fast reactor R\&D programs, including the DOE ART Program.

Major issues with Mod 9Cr1Mo are availability and welding. If the vessel is to be fabricated from stacked forged rings, one must weld the rings circumferentially, which is a difficult task. In the United States, one can weld a vessel from rolled semi-circular sections using longitudinal welds. There are very few forge shops that can forge rings of the size necessary for a large gas-cooled reactor vessel. Japan Steel Works may be the only one currently capable of such large forgings, but they have neither melting nor forging experience with Mod 9Cr-1Mo melting or forging, and they may decline to perform this work.

Grade 91 steel is challenging because it needs a very specific high-temperature solution heat treatment, quench and then tempering heat treatment. While it has been used in fossil steam generators, it has been be difficult to get vendors that are not used to working with this steel to carry out the proper heat treatment. Welding heavy sections, in particular, is challenging because it degrades the local heat treatment and material properties. For example, this welding process may lead to Type Four cracking in the heat affected zone adjacent to the weld metal; this is a type of failure that occurs at times well short of the predicted creep life. The solution to this problem is to either re-heat treat the steel (not recommended by vendors) or operate in a lower-temperature range to avoid creep. A significant characterization and testing effort would need to be conducted to determine whether Mod 9Cr-1Mo would be suitable for HTGR vessels. 
The remaining data needed for this material are the mechanical properties of heavy section products (base and weld metal), effects of aging and radiation, corrosion in helium environment, weldability risk, emissivity, negligible creep conditions, and creep fatigue. A specific test program on representative plates and forgings (including welded joints) will be required for component qualification. It has been estimated that the qualification of Mod $9 \mathrm{Cr}-1 \mathrm{Mo}$ will take approximately 72 months and $\$ 4 \mathrm{M}$, plus whatever time is required to submit and approve the code case, due to the need for procuring a large forging with a long lead procurement time. Mod 9Cr-1Mo is covered by the American Society of Mechanical Engineers (ASME Boiler and Pressure Vessel code up to $371{ }^{\circ} \mathrm{C}$ in Subsection NB and beyond $371{ }^{\circ} \mathrm{C}$ in Subsection NH). This subsection does not currently cover heavy section products and needs to be updated to cover specific aspects of Mod 9Cr-1Mo. Actions have already been launched in the context of the DOE/ASME Generation IV material project to provide a basis for code development.

\subsubsection{Modeling and Simulation}

Since the early days of the GGR concept, existing tools have been used to design and evaluate concepts. Because no GFR has been built, validation of these tools has not been possible. The basic neutronics of a fresh core can be captured with modern tools such as MCNP and SERPENT. Estimates of core neutronic parameters at high burnup can be made, but uncertainties in resonance parameters and other nuclear data inject considerable uncertainty that will only be reduced with operation of a plant. In the General Atomics design, neutronic coupling between the core and dual reflector materials may be complex and require validation using a critical experiment.

Thermal-fluidic analysis of GFRs under operating and accident conditions is challenged by the lack of data on gas cooling of a ceramic core. A matrix of separate effects and integral tests will need to be constructed and executed to generate validation data. The High Temperature Test Facility at Oregon State University is now generating data for validating models of prismatic HTGRs during depressurization events. This facility may be useful for GFR code validation, if the core internals can be re-configured to yield the thermophysical properties of GFR.

Given the anticipated development time of GFR fuel and cladding, there is time to develop multi-physics models and codes such as those being developed under the Nuclear Energy Advanced Modeling and Simulation and other DOE programs. Although the challenge of validating these high-fidelity models is significant, these models may capture the complex physics of GFR transients and provide key insights into fuel and system design.

\subsubsection{Licensing}

Data and information resulting from an advanced reactor research effort are often key parts of the technical development effort needed to successfully license a nuclear plant. Consequently, test plans and conclusions that support a technology safety case and demonstrate regulatory compliance should consider those requirements, while protocols are planned and performed. Properly informed planning helps ensure technology research activities adequately address later licensing needs. The ART Program regulatory technology development plan links major research activities in advanced non-light water reactor technologies to key regulatory requirements and licensing challenges likely to affect deployments in the domestic commercial energy market [22]. In response to ART Program research priorities, the ART regulatory technology development plan currently focuses on two technology types likely to undergo Nuclear Regulatory Commission (NRC) safety review within in the next 20 years, (i.e., the modular HTGR and the sodium-cooled fast reactor).

Establishing links between reactor research and licensing is complex and requires interaction and coordination with the design community, NRC staff, and researchers working to bring conceptual system designs to maturity. The ART regulatory technology development plan was created to aid that linkage and further the NRC's Advanced Reactor Policy Statement of 2008 (restated in the Nuclear Regulatory Commission's 2012 Report to Congress on Advanced Reactor Licensing) [23]. This statement encourages reactor research in new safety and security features or proposals for simplified, inherent, and passive means for accomplishing a safety or security function. This information is then to be presented to NRC staff to help 
assure adequate confirmatory testing, provide for collection of sufficient data to validate computer codes, and show that system interaction effects are acceptable. To support deployment of GFRs, the ART regulatory technology development plan should be expanded to include this reactor concept, focusing on the General Atomics $\mathrm{EM}^{2}$ because it is the only U.S.-based GFR design currently under development.

\section{SCHEDULE}

Figure 5 shows the high-level schedule for completing the identified R\&D tasks. This schedule assumes that the ex-core materials and components developed for the VHTR would be used in the GFR.

\section{SUMMARY}

An R\&D roadmap has been constructed to support commercial demonstration of a GFR by 2030 . Because the GFR is a relatively immature technology with challenging requirements for fuel/cladding performance and DHR, most of the R\&D must focus on the development and qualification of the ceramic fuel form (carbide or nitride) and the $\mathrm{SiC}$ cladding. Strong emphasis must be placed on development and testing of a reliable and powerful DHR system. The first item is the 'long pole in the tent' because of the length and complexity of the required irradiation experiments and post-irradiation examination (for fuel and cladding).

The special infrastructure needed to do this work (i.e., high-flux materials test reactor and hot cell facilities) is available only within the DOE complex. Even then, the available materials test reactors produce a relatively low fast flux needed for reproducing damage in fuel and cladding candidates. Basic testing of these materials must commence soon in order for adequate fluences to be attained in candidate materials.

A matrix of separate, mixed, and integral effects experiments must be designed and carried out, ideally with a number of university and international partners. These will provide data needed to validate as-yet developed codes and models.

As with the VHTR power conversion system, the operating parameters of which are very similar to the GFR, a component test facility will be needed to complete testing and qualification of valves, circulators, and other equipment needed for a first-of-a kind power plant. Research into new materials is required to support demonstration of a GFR. Materials being developed for the VHTR (with outlet temperatures greater than $800^{\circ} \mathrm{C}$ ), metallic alloys, and composites that can withstand the higher temperatures will need to be qualified and incorporated into the ASME code. Likewise, components made of alloys (e.g., heat exchangers and steam generators) will need to be designed and tested. Alloys 617, 800H, and Mod 9Cr-1 Mo are currently undergoing testing at laboratories in the DOE complex. Supporting deployment of a GFR by 2030 will require many tasks to be performed in parallel. 


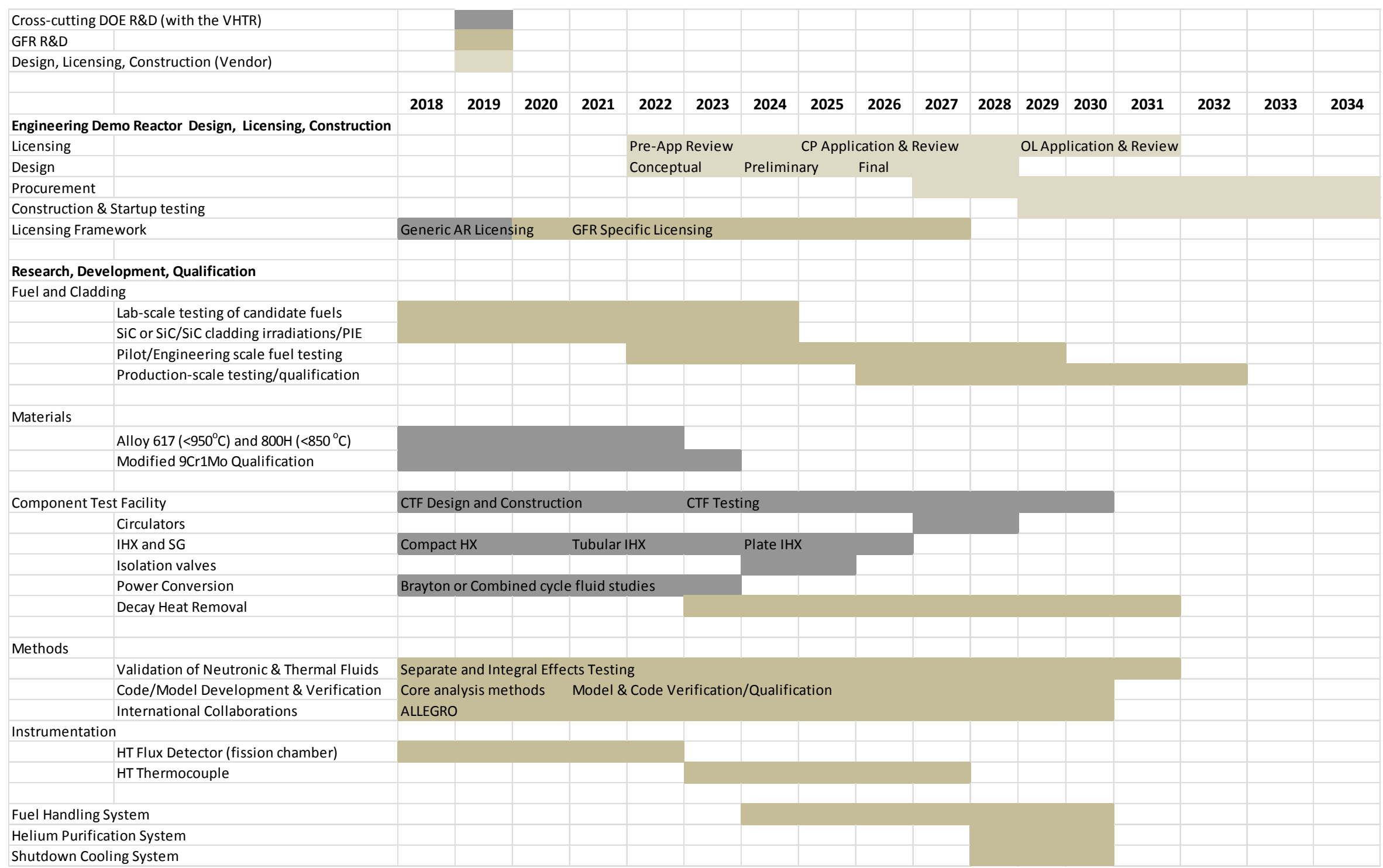

Figure 5. Approximate schedule for supporting GFR engineering demonstration. 


\section{REFERENCES}

[1] Van Rooijen, W. F. G., 2009, "Gas-Cooled Fast Reactor: A Historical Overview and Future Outlook," Science and Technology of Nuclear Installations, Hindawi Publishing Corporation, Volume 2009, Article ID 965757.

[2] DOE, 2002, A Technology Roadmap for Generation IV Nuclear Energy Systems, issued by the U.S. DOE Nuclear Energy Research Advisory Committee and the Generation IV International Forum.

[3] OECD Nuclear Energy Agency, "Technology Roadmap Update for Generation IV Nuclear Energy Systems," January 2014.

[4] Richmond, R., 1982, "Measurement of the Physics Properties of Gas-Cooled Fast Reactors in the Zero Energy Reactor PROTEUS and Analysis of the Results," EIR-Bericht Nr. 478, Eidg. Institut fur Reaktoforschung Wurenlingen, December 1982.

[5] Heer, W. and P. Wydler, 1973, "PROTEUS, Das schnell-thermishe SYSTEM PROTEUS; theoretische Ergebnisse," EIR Internal Document, TM-PH-404.

[6] Seth, S. and R. Richmond, 1975, "Measurement and Calculation of Integral Cross-Section Ratios in a Central Breeder Zone in a GCFR Lattice," ANS Transactions 21, 460.

[7] Perret, G., R. M. Pattupara, G. Girardin, and R. Chawla, 2012, "Reanalysis of the Gas-cooled Fast Reactor Experiments at the Zero Power Facility PROTEUS - Spectral Indices," PHYSOR 2012, Knoxville, Tennessee, April 15 through 20, 2012.

[8] Stainsby, R., J. C. Garnier, P. Guedeney, K. Mikityuk, T. Mizuno, C. Poette, M. Pouchon, M. Rini, J. Somers, and E. Touron, 2011, "The Generation IV Gas-cooled Fast Reactor," Paper 11321, Proceedings of ICAPP 2011, Nice, France, May 2 through 5, 2011.

[9] AREVA, 2007, "NGNP with Hydrogen Production Preconceptual Design Studies Report - Executive Summary," AREVA Document \#12-9052076-001, June 2007.

[10] DOE, Advanced Reactor Concepts Technical Review Panel Report-Evaluation and Recommendations for Future R\&D on Eight Advanced Reactor Concepts, Department of Energy, November 2012.

[11] DOE, 2011, “Technology Readiness Assessment Guide," DOE Guide 413.3-4A, U.S. Department of Energy, September 2011.

[12] Gougar, H., R. Bari, T. K. Kim, T. Sowinski, and A. Worrall, 2015, Assessment of the Technical Maturity of Generation IV Concepts for Test or Demonstration Reactor Applications, INL/EXT-1536427, Revision 1, Idaho National Laboratory, October 2015.

[13] Tracy, G., 2014, "Next Generation Nuclear Plant-Assessment of Key Licensing Issues," Letter to John E. Kelly, Nuclear Regulatory Commission, July 2014.

[14] AREVA, 2009, NGNP Technology Readiness Levels for Conventional Steam Cycle Configuration, TDR-3001463-000, March 2009.

[15] Collins, J., 2009, Next Generation Nuclear Plant Technology Development Roadmaps: The Technical path Forward, INL/EXT-08-15148, Idaho National Laboratory, January 2009.

[16] Poette, C. et al, 2013, "Gas Cooled Fast Reactors: Recent Advanced and Prospects," Proceedings of the International Conference on Fast Reactors and Related Fuel Cycles (FR13), Paris, France, March 2013.

[17] Kim, T. K. et al, 2009, "Carbide and Nitride Fuels for Advanced Burner Reactor," Proceedings of the International Conference on Fast Reactors and Related Fuel Cycles (FR09), Kyoto, Japan.

December 2009. 
[18] Crawford, D. C., D. L. Porter, S. L. Hayes, M. K. Meyer, D. A. Petti, and K. Pasamehmetoglu, 2007, “An Approach to Fuel Development and Qualification," Journal of Nuclear Materials 371, 232-242.

[19] Sengupta, A. K., U. Basak, A. Kumar, H. S. Kamath, S. Banerjee, 2009, “Experience on mixed carbide fuels with high 'Pu' content for Indian fast breeder reactor - An overview," Journal of Nuclear Materials 385, 161-164.

[20] Varatharajan, S., K. V. Sureshkumar, K. V. Kasiviswanathan, and G. Srinivasan, 2010, "Progressive Evolution of the Core of the Fast Breeder Test Reactor," ICONE18, Xi'an, China.

[21] Petti, D. A., 2010, Updated NGNP Fuel Acquisition Strategy, INL/EXT-07-12441, Idaho National Laboratory, December 2010.

[22] Moe, W., 2015, “Advanced Reactor Technology - Regulatory Technology Development Plan (RTDP)," PLN-4910, Idaho National Laboratory, May 2015.

[23] Report to Congress: Advanced Reactor Licensing, US Nuclear Regulatory Commission, August 2012. 